UDK 81'246.2(497.113)

$811.162 .4 ' 246.2(497.113)$

$811.163 .41 ' 246.2(497.113)$

DOI 10.18485/primling.2015.16.9

Anna Makišová

Filozofická fakulta, Nový Sad

Oddelenie slovakistiky

\title{
SPISOVNÁ SLOVENČINA V BILINGVÁLNOM PROSTREDÍ
}

\begin{abstract}
Abstraktné: Predmetom výskumu sú prejavy vojvodinských Slovákov (písané a hovorené). Slovenčina vo vojvodinskom prostredí sa dennodenne dostáva do kontaktu so srbčinou, čo značne vplýva na vyjadrovanie. Zvlášt' je to výrazné u používatel'ov mladšej populácie, hlavne ked' ide o súčasné trendy, nové pomenovania, ktoré sa preberajú zo srbčiny. Kontakt vojvodinskej slovenčiny so srbčinou je prirodzený a nevyhnutný. Vojvodinskí Slováci ovládajú oba jazykové systémy (slovenčinu a srbčinu) dostatočne pre každodenné používanie.

Žijeme v bilingválnom prostredí, na dorozumievanie okrem slovenčiny používame aj srbčinu, ktorá ovplyvňuje naše vyjadrovanie. Pod vplyvom srbského jazyka použité lexémy často nadobúdajú inú podobu, nespisovnú a paralelne nastáva posun aj v sémantike (pridat' - odovzdat'; vypravit' - opravit'; Slováčka - Slovenka; nastavit' - pokračovat' a pod.).
\end{abstract}

Kl'účové slová: Slovenský jazyk, srbský jazyk, bilingvizmus, sémantika.

Predmetom nášho výskumu sú písané a hovorené prejavy vojvodinských Slovákov. Žijeme v bilingválnom prostredí, na dorozumievanie okrem slovenčiny používame aj srbčinu, ktorá ovplyvňuje naše vyjadrovanie. Pod vplyvom srbského jazyka použité lexémy často nadobúdajú inú podobu, nespisovnú a paralelne nastáva posun aj v sémantike. Slovenčina vo vojvodinskom prostredí sa dennodenne dostáva do kontaktu so srbčinou, čo značne vplýva na vyjadrovanie. Zvlášt' je to výrazné u používatel'ov mladšej populácie, hlavne ked' ide o súčasné trendy, nové pomenovania, ktoré sa vel'mi často preberajú zo srbčiny. Kontakt vojvodinskej slovenčiny so srbčinou je prirodzený a nevyhnutný. Výsledkom takéhoto kontaktu je slovensko-srbský bilingvizmus. Vojvodinskí Slováci ovládajú oba jazykové systémy (slovenčinu a srbčinu) dostatočne pre každodenné dorozumievanie. Profesorka Myjavcová píše, že pre spisovnú slovenčinu vo Vojvodine platí tá istá spisovná norma a tie isté kodifikačné pravidlá ako v spisovnej slovenčine na Slovensku (Myjavcová, 2006) aj ked’ často niektorí jazykovedci na Slovensku hovoria, že je to iná slovenčina. K takémuto tvrdeniu sa $\mathrm{v}$ žiadnom prípade neprikláňame, je to spisovná slovenčina, ktorá je organickou súčast'ou spisovnej slovenčiny na Slovensku, len je to jazyk, ktorý žije a uplatňuje sa $\mathrm{v}$ iných podmienkach, $\mathrm{v}$ kontakte so srbčinou. $\mathrm{V}$ každom ohlade a za každých podmienok opierame sa o kodifikačné príručky, ktoré platia na Slovensku. „Bilingvista totiž pri spomínanej komunikácii nie je schopný spolahlivo 
rozhtraničt' svoje dva jazyky, takže sa v podstate stáva sprostredkovatel’om prenášania prvkov srbského jazyka do svojho materinského jazyka“. (Myjavcová: 2015, 11) V takýchto situáciách každého hovoriaceho do prejavu sa dostávajú rozličné srbské slová, niekedy sú to slová prispôsobené zákonitostiam slovenského jazyka, kalky, a na ten spôsob sa narúša spisovná podoba jazyka. Môžeme konštatovat', že vplyvy tohto druhu sú častejšie $\mathrm{v}$ hovorenej podobe slovenčiny než v písanej podobe, lebo hovorená podoba vzniká spontánne, pričom subjektívne činitele majú silnejší vplyv. Hovoriaci, používatel' jazyka, dokonca nemá možnost' nahliadnut' do ktorejkolvvek príručky, aby si tak overil, či dané slovko správne alebo nesprávne použil v danej situácii. Srbský jazyk má u nás povahu dominantného jazyka. Myslíme tu najmä na prostriedky hromadného informovania tlač, rozhlas, televíziu, pričom príslušníci slovenského jazykového spoločenstva sú vo väčšine pasívnymi účastníkmi. Pre nich srbský, kontaktový jazyk nie je žiadnou zátažou, ale môžeme povedat', že aj to ovplyvňuje ich jazyk, ked’že dennodenne sa k nim dostávajú informácie po srbsky. Vojvodinskí Slováci sa tak priamo prepínajú z jedného jazyka na druhý. Treba pripomenút', že národnostné menšiny v Republike Srbsko majú právo používat' svoj jazyk a písmo v oblasti vzdelávania, v prostriedkoch verejného informovania, v administratívno-právnej oblasti, v oblasti náboženstva a pod. Všetky spomenuté oblasti sú regulované rôznymi právnymi predpismi. Ústavou Republiky Srbsko je regulované, že úradným jazykom je srbčina, písmo cyrilika. Zákonom sa upravuje úradné používanie iných jazykov. Príslušníci národnostných menšín majú právo na používanie vlastného jazyka a písma, a to najmä v tých oblastiach, kde tvoria väčšinu. V takých oblastiach sa uplatňuje právo na vyučovanie $\mathrm{v}$ svojom rodnom jazyku, právo používat' jazyk menšiny $\mathrm{v}$ úradnom styku $\mathrm{v}$ miestnych orgánoch samosprávy a právo na použivanie materinského jazyka aj v iných sférach verejného života. Preto je žiaduce, aby vo svojom vyjadrovaní, najmä ked' ide o verejné prejavy, dodržiavali normy spisovnej slovenčiny a tak vplyv srbského jazyka bude minimálny.

Lexémy a spojenia, ktoré sme zaznamenali zaradili sme ich ku kalkom. Kalky vznikajú pri kontakte s iným jazykom, ked’ sú používatelia jazyka dlhšie vystavení vplyvu iného jazyka. $V$ takých podmienkach použivania jazyka väčšinový jazyk, v našom prípade srbský jazyk, vplýva na jazyk, vyjadrovanie príslušníkov menšinového jazykového spoločenstva, konkrétne vojvodinských Slovákov. Tak potom slová, konštrukcie z dominantného jazyka sa prenášajú do menšinového jazyka. Ďalej prevzaté prvky sa prispôsobujú, adaptujú v prebranom, konkrétne menšinovom, slovenskom jazyku. Prebrané prvky $\mathrm{v}$ jazyku sa adaptujú prevažne na fonetickej a morfologickej rovine. Ide o kopírovanie štruktúry srbského slova. Zvyčajne $\mathrm{k}$ srbskému slovu, t.j. časti slova dosadí sa slovenská predpona, prípona alebo bud' koreň. V niektorých prípadoch srbské slovo nadobudne dížku, resp. mäkkost'. Alebo môže sa aj viacslovné pomenovania nahradit' slovenskými slovami.

Vel'mi často u našich žiakov, študentov počujeme spojenie seminárnu prácu pridáme, dokedy máme pridat seminárnu prácu, dokonca už aj u študentov, ktorí končia štúdiá pridat diplomovú prácu a podobne. Lexéma pridat' do vyjadrovania vojvodinských Slovákov sa dostala pod vplyvom srbčiny, ide o kalk, doslovný preklad zo srbčiny predati seminarski rad, predati diplomski rad. K srbskému slovesu hovoriaci dosadil slovenskú predponu pri-. V tomto kontexte treba upozornit' a uviest', že sloveso pridat' a zvratná podoba pridat' sa, sa vyskytuje aj v spisovnej slovenčine, ale význam slovesa je celkom 
odlišný a nepoužívame v spojení pridat' seminárnu prácu. Ked' ide o nezvratnú podobu sloveso pridat' podl'a Krátkeho slovníka slovenského jazyka má dva významy (KSSJ: 349): 1. dodat' k pôvodnému stavu, množstvu pridat' do polievky sol' a pod. A druhý význam zväčšit', zvýšit', rozmnožit' pridat' plyn a zvratné sloveso pridat' sa vo význame pripojit' sa alebo stat' sa prívržencom niekoho, napr. pridat' sa k návrhu. Ani jeden z uvedených významov nemôžeme použit' v uvedenom kontexte. Ak použijeme v spomenutom kontexte sloveso pridat', sémantika sa mení. V uvedenej vete sa žiada použit' sloveso odovzdat': odovzdat' seminárnu prácu, diplompvú prácu a pod.

V spojení prepustila som poviedat nastal posun vo význame slovesa prepustit'. Lebo, sloveso je použité pod vplyvom srbského jazyka. Aj v spisovnej slovenčine sa vyskytuje sloveso prepustit', ale s odlišným významom ako v srbčine. Hovoriaci chcel povedat', že niečo vynechal, zabudol povedat'. V spisovnej slovenčine sloveso prepustit' má šest' významov (KSSJ: 342): pustit' na slobodu, zbavit' povinností, dovolit' odíst', umožnit' preniknutie niečoho, povolit' realizáciu a zriect' sa v niečí prospech. Ani jeden význam nie je adekvátny s naším hore uvedeným dokladom. Ako aj v predchádzajúcom doklade ku srbskému slovesu je pridaná slovenská predpona pre-. Správne spojenie znie: zabudla som povedat'.

Kalkovaním často vzniká slovo, ktoré v slovenčine nie je známe, ale i slovo, ktoré je formálne slovenské, ale má iný význam, než je význam kalkovaného srbského slova a daný význam sa v slovenčine vyjadruje iným slovom.

$\mathrm{K}$ tejto skupine slov zaradíme aj spojenie: nemáme tlačiarničku vo farbe. Ide o doslovný preklad srbského spojenia: štampač u boji. Ked’že vo väčšine prípadov srbskú predložku u prekladáme do slovenčiny $\mathrm{v}$, resp. vokalizovanú podobu vo ked' si to spojenie slov vyžaduje, tak aj v spojenie $u$ boji podávatel' informácie preložil vo farbe. $\mathrm{V}$ spisovnej slovenčine sa vlastnost' podstatného mena vyjadrujeme prídavným menom, na syntaktickej rovine ide o prívlastok. A pozícia zhodného prívlastku je pred podstatným menom. Tak uvedené spojenie v spisovnej slovenčine znie farebná tlačiareň, podobne ako makový koláč, čokoládová torta, novosadský autobus a pod. Ešte $\mathrm{k}$ tomuto spojeniu treba pripomenút', že nepoužívame deminutívne podstatné meno tlačiarnička, ale tlačiareň, aj ked' pomenúvame malý prístroj, na rozdiel od vel'kých tlačiarenských strojov.

Vo vete: Na účely konferencie sme odvojili peniaze. srbské sloveso odvojit' je začlenené do slovenského kontextu. Spomenuté sloveso sa často vyskytuje v prejavoch realizovaných po slovensky. Rovnako ako aj v predchádzajúcich dokladoch srbské sloveso odvojiti je zakomponované do slovenského kontextu. Sloveso sa adaptovalo na fonetickej a morfologickej rovine. Ide o nenáležité spojenie a namiesto slovesa odvojit' treba vo vete použit' sloveso vyčlenit'.

Nn mieňa učitel'ku, ktorá je na materskej dovolenke. Sloveso mieňat' je prebrané zo srbského jazyka, v slovnej zásobe spisovnej slovenčiny sa nevyskytuje. Ide o kalk. Bežne v prejavoch vojvodinských Slovákov sa vel'mi často vyskytuje, aj u mladšej, aj u staršej generácie. V srbčine máme sloveso menjati, ktoré ma 6 významov a v prejavoch vojvodinských Slovákov sa adaptovalo na fonetickej rovine. Ekvivalentné slovenské slovo v spomenutej konštrukcii bude: zastupovat' - nahradit' v práci, v činnosti: zastupuje učitel'ku, ktorá je na materskej dovolenke.

Vo vete Svesňí sme, že vo vyjadrovani použivame nárečie; lexéma svesňi je kalk srbskej lexémy svestan. Prispôsobovanie nastalo na fonetickej rovine zmäkčovanie a dí- 
ženie samohlásky. Spomenuté prídavné meno sa nevyskytuje v spisovnej slovenčine a mali by sme ho vystriedat' spisovnou podobou: vedomí sme, uvedomujeme si, že vo vyjadrovaní používame nárečie.

Pod vplyvom srbského jazyka je použité aj podstatné meno chala: športová chala. Podávatel' informácie v slovenskom kontexte použil srbskú lexému. Existuje aj v slovenčine podobné podstatné meno, len namiesto fonémy ch sa používa fonéme h: hala, teda športová hala.

Ďalej sme si všimli, že pre príslušníčku slovenského národa na našich priestoroch vel'mi často sa používa lexéma Slováčka. Tvorenie môžeme porovnat's tvorením prechýlených podôb z mužských podostatných mien, ktoré sa končia na spoluhlásku -k: jedinák, prvák, žiak. Prechýlená podoba $\mathrm{z}$ uvedených podstatných mien bude jedináčka prváčka, žiačka a podl’a analógie aj tvar Slováčka. Tvar Slováčka nenájdeme ani v jednom slovníku slovenského jazyka, spisovný tvar je Slovenka rovnako ako aj Srbka, Nemka, Čiernohorka a pod.

Lexémy, ktoré sme hore uviedli, sa v slovenských vetách adaptovali, prispôsobili systému slovenského jazyka. Adaptovali sa prevažne na fonetickej a morfologickej rovine. Ked’že v konkrétnom prípade ide o kontakt dvoch blízko príbuzných jazykov, ich fonetický a morfologický systém sa nie vel'mi líšia, takže adaptácia srbských slov ako na fonetickej, tak aj na morfologickej rovine prebieha každodenne.

V našej vojvodinskej slovenčine sú aj také slová, ktoré sú aj v spisovnej slovenčine na Slovensku, ale sa používajú na označenie inej reálie alebo v inom kontexte ako u nás. Všimli sme si lexému vychovávatel'ka. V srbčine sa bežne používa vaspitačica, dokonca v Rečniku srpskog jezika (Novi Sad: 2007, 131) sú zaradené párne lexémy vaspitač - vaspitačica. V slovenčine je frekventovaná lexéma vychovávatel'ka, utvorená podl'a srbského modelu, lebo spomenuté povolanie si najčastejšie volili a volia osoby ženského pohlavia. V súvislosti s feminatívom vychovávatel'ka treba doložit', že pre spomenuté povolanie na Slovensku sa bežne používa spojenie učitel'ka materskej školy. Vychovávatelia sú skôr zastúpení v domovoch (žiacky domov, domov mládeže a pod.). Podobne aj ked’ ide o pomenovanie obec $\mathrm{v}$ inom kontexte sa používa u nás, vo Vojvodine, a v inom kontexte na Slovensku. Sú aj také pomenovania, ktoré boli vo vojvodinskej slovenčine utvorené, lebo si to vyžiadalo naše spoločensko-politické zriadenie: obecné zhromaždenie, autonómna pokrajina, miestne spoločenstvo a pod.

Naši žiaci na základných školách (a nielen žiaci) používajú spojenie žiacka knižoč$k a$. O čo tu ide? V konkrétnom spojení ide o doslovný preklad zo srbčiny: đačka knjižica. V slovenčine zdrobnené podstatné meno ku slovu kniha je knižka. Náležité spojenie bude žiacka knižka. Zdrobnené podstatné meno knižočka je označené v KSSJ ako expresívne. Do tejto skupiny slov a slovných spojení môžeme zaradit' aj spojenie predškolská ustanovizeň. Treba pripomenút', že na Slovensku na označenie ustanovizne, ktorú navštevujú deti vo veku jeden až šest' rokov, používajú pomenovanie materská škola. U nás, vo vojvodinskom prostredí, na označenie rovnakej inštitúcie sa bežne používa spojenie predškolská ustanovizeň. Uvedené pomenovanie zvykneme vel'mi často vystriedat' aj lexémou škôlka. V KSSJ lexéma škôlka je označená ako hovorové slovo. Ak si všimneme správy zverejnené v elektronickej forme, aj tam sa môžeme presvedčit' o uvedenom tvrdení. Všetky správy zo Slovenska uvádzajú spojenie materská škola, kým v správach z Vojvodiny je zastúpené spojenie predškolská ustanovizeň. Môžeme to vyvodit' na základe 
srbského jazyka predškolska ustanova $\rightarrow$ predškolská ustanovizeň. rozdiel v používaní pomenovaní na relácii Slovensko - Vojvodina zaznamenali sme aj ked’ ide o preukaz každého jednotlivca hociktorého štátu. Na Slovensku sa používa spojenie občiansky preukaz, kým u nás, vo vojvodinskej slovenčine, je zaužívané spojenie osobný preukaz. Svojho času aj osobné preukazy boli dvojjazykové, možno spomenutá prax bude znovu aktuálna, na prvej strane preukazu po slovensky bolo napísané: osobný preukaz. Uvedieme ešte jednu lexému, ktorú sme zaznamenali v novosadskom rozhlase, ktorý vysiela po slovensky, ale aj v týždenníku Hlas l'udu (č.11: 15): stretnutie vidieckych žien. To, čo bolo pre nás takou zvláštnost'ou, je prídavné meno vidieckych. Nemôžeme povedat', že lexéma nie je použitá v duchu slovenčiny, ba naopak, ide o adekvátnu lexému, len to čo bolo pre nás nezvyčajné, že v našom prostredí sa bežne nepoužíva podstatné meno vidiek, zaužívané je dedina. Ide o to, že k našim reáliám zvykneme používat' naše pomenovania, aby sme naplno vystihli náš spôsob života.

Kdže máme možnost' sledovat' televíziu Markíza, prednedávnom sme si všimli aj rozdiely, ked' ide o používanie predložky v a na: v Kosove a na Kosove. V slovenskom vysielaní sme zaznamenali spojenie Ty si v Kosove nebola, kým vo vojvodinskej slovenčine sa bežne používa predložka na: na Kosove, rovnako, ako aj v srbčine. O zastúpení predložiek v a na písal Ján Horecký. Ide hlavne o zastúpenie nižšia poloha, vyššia poloha, aj z hl'adiska terénu, či je niečo južne alebo severne. Ak sa niečo deje vnútri, ak ide o uzavretý priestor, umiestnenie $\mathrm{v}$ tom priestore sa vyjadruje predložkou v (v Turci, v Gemeri, v Šariši). Vo vojvodinskom prostredí sa bežne používa v tomto kontexte predložka na. Uvedieme doklady, ktoré nám potvrdzujú, že sa vo vojvodinskom prostredí používa predožka na: Situácia so záplavami na Kosove nie je alarmujúca. (www.rtv.rs 8.1.2016); Lajčák o vol'bách na Kosove (www.rtv.rs 15.11.2013); Inštitúcie na Kosove v spolupráci s medzinárodnými organizáciami by sa mali poučit zo situácie v prvom kole lokálnych volieb na Kosove. (www.rtv.rs 15.11.2013). Pokúsime sa odpovedat' na otázku: Ktorá predložka je náležitá, v alebo na? Používajú možno vojvodinskí Slováci predložku na pod vplyvom srbčiny? Na základe lokalizácie vnútri niečoho je použitá predložka v vo vete: V Kosove si nebola. Vyjadruje miesto, vnútri toho štátneho útvaru sa niečo deje. Uvedieme aj d'alšie doklady, ktoré sú prístupné v eletronických médiách (sú to doklady z médií zo Slovenska). Ludia sa v Kosove neusmievajú. Kontrast kosovských ciest vyhrocujú obrnené vozidlá Eulex (špeciálna misia EÚ v Kosove) a KFOR. (www. hiking.sk 13.01.2014) Srbsko chce usporiadat' vol'by v Kosove. Rusi poslali pre Srbov v Kosove pomoc. (www.spravy.pravda.sk 2.04.2008) Z dokladov vyplýva, že na Slovensku sa používa predložka v a vo vojvodinskom prostredí príslušníci slovenského jazykového spoločenstva použivajú predložku na s podstatným menom Kosovo v lokáli na označenie miesta. Rovnako tak použijeme predložku v aj vo vetách: V Srbsku žijú Slováci. Nespomeniem si, kedy som bola poslednýkrát v Chorvátsku. Minulý rok som bola v Sarajeve. Vo Vojvodine je úrodná pôda. V Novom Sade žijú Slováci. Uviedli sme doklady, v ktorých je použitá predložka $v$ v spojení s názvami krajín, územných celkov, miest. Teda, aj vo vete: Ty si v Kosove nebola, ide o rovnaké vyjadrenie. Teraz si tu môžeme položit' otázku, prečo potom používame predložku na napr. vo vete: Minulý týždeň som bola na Slovensku. Tu rovnako tak ide o krajinu, v ktorej som bola. V konkrétnej vete nepoužijeme predložku v. Horecký v štúdii píše, že ked’ ide o používanie predložiek na a v dôležitý je aj vzt’ah centrum - periféria, či sa niečo nachádza vyššie alebo nižšie, severne alebo južne, napr. 
na Starej Turej, na Myjave, na Orave, na Kysuciach, na Záhori, ale oproti tomu bude v Turci, v Gemeri, v Honte. Ak si bližšie pozrieme mapu Slovenska, hned’ nám uvedená konštatácia bude jasnejšia. Oblasti Slovenska, ktoré sú geograficky uložené severnejšie, pri označovaní lokality použijeme predložku na: na Spiši, na Myjave, na Kysuciach, na Záhorí a pod. A oblasti, ktoré sú teritoriálne umiestnené južnejšie, na označenie a vyjadrenie miesta budeme používat' predložkou v: v Gemeri, v Honte, v Novohrade, v Podunajsku a pod. Podl'a uvedeného výkladu vyplýva aj naša odpoved' na otázku: máme použit’ spojenie v Kosove alebo na Kosove? Z hl'adiska Slovákov žijúcich na Slovensku predložka v je náležite použitá. Ide o označenie miesta, pád lokál a z hl'adiska teritoriálneho ide o územie, ktoré sa vyskytuje južnejšie, teda predložka v. Rovnako použijeme predložku v aj ked' ide o spojenia v Macedónsku, v Grécku a pod. Ked' ide o používanie predložky na u vojvodinských Slovákov, tu môžeme konštatovat', že ide o interferenciu (Ty si na Kosove nebola). Lebo podl'a hore uvedeného, ide o označenie miesta, ktoré sa nachádza južne, teda správne bude predložka v: v Kosove. Dokonca aj ked’ ide o vyjadrenie miesta na osi sever - juh, aj ked' ide o vojvodinského používatel'a, žiada sa predložka v: ide o umiestnenie v južnej časti, v Kosove.

Ktorú predložku použivat', ked' ide o vyjadrenie miesta, lokalizovanie miesta a pohoria. Poznáme z praxe spojenia: bola som v Tatrách, v Alpách, ale ktorú predložku použijeme v spojení: bola som na Zlatibore, na Kopaoniku alebo v Zlatibore, v Kopaoniku? Z praxe bežne nám je známe, že vojvodinski Slováci v tomto kontexte použivajú predložku na. Rovnako tak ako čo sú Alpy a Tatry, aj Zlatibor, Kopaonik pomenúvajú pohoria. Môžeme si položit' otázku, máme použivat' bola som v Zlatibore, v Kopaoniku? Uvedieme niekol'ko dokladov z elektronických médií zo Slovenska: má kontakty v Srbsku na trénerov, ktorí robia kemp v Zlatibore; Kemp v Zlatibore privital po roku opät' hráčov Karlovky; (www.mbkkarlovka.sk) ...,,hry priatel'stva“ v Zlatibore, Srbsku. (www.consulatme.sk) a doklady z elektronických médii zo Srbska: Naša organizácia sa zúčastnila na Zlatibore podpísania dohôd...(www.aerd.org.rs) Na Zlatibore veda a prax spoločne (www.hl.rs). Možno konštatovat', že predložka na vo vojvodinskom prostredí sa použiva pod vplyvom srbského jazyka. Ked' ide o Frušskú horu, tak tu bežne použivame spojenie: bola som vo Frušskej hore.

Na zachovanie a udržanie slovenského jazyka v bilingválnom prostredí dôležité je už od začiatkov výchovy, od materskej školy, det'om vštepovat' lásku k spisovnému jazyku. Ale vždy musime mat' na zreteli, aký je ten náš prejav, to naše vyjadrovanie. Každý jednotlivec musi prihliadat', aby vo svojom vyjadrovaní nepoužival srbské alebo „zdanlivo slovenské slová “, lebo diet'a si vel'mi všima a vpija každé slovo svojej učitel'ky. A potom samozrejme pokračovat' na úrovni základnej školy. Neustále sa zdokonal'ovat', aj ked' už nie sme školopovinní, mat' pozitívny vzt'ah ku svojmu materinskmu jazyku. Každý hovoriaci by sa mal usilovat', aby svoj jazykový prejav povzdvihol na vyššiu úroveň. Neustále sa zdokonal'ovat' a nebyt' l'ahostajným. Mienime, že je vel'mi dôležité aby každý príslušník slovenského jazykového spoločenstva mal pozitívny vzt'ah k slovenčine a vtedy nebude mat' l'ahostajný postoj ku svojmu jazyku, ale bude sa snažit', aby úroveň jeho prejavov bola na čoraz vyššej úrovni. Samozrejme, aj jazyková politika štátu musí byt’ pozitívna k nášmu materinskému jazyku. 


\section{Literatúra}

Hlas l'udu, r. 73, č. 11, 12.3.2016

Horecký, J. (1998). Konkurencia predložiek v a na. Kultúra slova, 32, 193-197.

Krátky slovnik slovenského jazyka (1987). Bratislava: Veda, vydavatel'stvo SAV.

Myjavcová, M. (2006). State o našej slovenčine. Báčsky Petrovec: Kultúra.

Myjavcová, M. (2015). O slovensko-srbskom bilingvizme vo Vojvodine. Báčsky Petrovec: Slovenské vydavatel'ské centrum.

Rečnik srpskoga jezika (2007). Novi Sad: Matica srpska.

\section{Zdroj:}

www.aerd.org.rs

www.hiking.sk

www.hl.rs

www.mbkkarlovka.sk

www.rtv.rs

www.spravy.pravda.sk

\section{Anna Makišová}

\section{LITERARY SLOVAK LANGUAGE IN BILINGUAL ENVIRONMENT}

Summary: The topic of research presented in this paper is the discourse of Vojvodinian Slovaks (both written and spoken). We live in a bilingual setting so, when communicating, we use Serbian besides Slovak, which influences the way we express ourselves. Under the influence of the Serbian language the lexemes used in speech and writing often have a different, non-literary form, which results in a parallel semantic shift.

Key Words: Slovak language, Serbian language, bilingualism, semantics. 